UDC 338.48:616-036.21

DOI https://doi.org/10.26661/hst-2020-7-84-15

\title{
TOURISM - A TOOL FOR ECONOMIC DIVERSIFICATION FOR OTHER SECTORS
}

\author{
C SVAGZDIENE, BIRUTA \\ Prof.dr. Department Sport and Tourism Management, Lithuanian Sports University (Kaunas, Lithuania) \\ E-mail: biruta.svagzdiene@1su.1t \\ ORCID iD: https://orcid.org/0000-0001-6016-6019 \\ Каунаський університет спорту, 6, Каунаський повіт, 44221 Каунас, Литва \\ Lithuanian Sports University, 6, str. Sporto, Kaunas municipality, 44221 Kaunas, Lithuania
}

(C) STREIMIKIENE, DALIA

Habil. Dr., Prof. Institute of Sport Science and Innovations, Lithuanian Sports University (Kaunas, Lithuania)

E-mail: dalia.streimikiene@1su.1t

ORCID iD: https://orcid.org/0000-0002-3247-9912

Каунаський університет спорту, 6, Каунаський повіт, 44221 Каунас, Литва

Lithuanian Sports University, 6, str. Sporto, Kaunas municipality, 44221 Kaunas, Lithuania

\section{(C) JASINSKAS, EDMUNDAS}

Prof.dr., Vice-Rector for Research, Lithuanian Sports University (Kaunas, Lithuania)

E-mail: edmundas.jasinskas@1su.1t

ORCID iD: https://orcid.org/0000-0003-3158-2974

Каунаський університет спорту, 6, Каунаський повіт, 44221 Каунас, Литва

Lithuanian Sports University, 6, str. Sporto, Kaunas municipality, 44221 Kaunas, Lithuania

\begin{abstract}
Abstarct
The relevance of this study. The perception of tourism as a viable economic activity is very closely linked to competitiveness. In the international tourism market, European tourism is seen as facing increasing competition from emerging economies on other continents. However, the tourism business is seen as a determinant of the competitive positions of economic diversification. Tourism in the European Union is seen as a fast-growing area of the tourism sector that can contribute to the overall growth of the sector, while tackling social problems and creating new jobs. International tourism and its economic significance is a little-studied topic in the scientific literature, and its development through the prism of economic diversification has an increasing impact on the country's economy.

The main problem. What impact do tourism business innovations have on other tourism-related sectors, and what impact is felt during the COVID-19 pandemic?

The objectives of the study are: promoting the competitiveness of tourism and the resulting economic impact in the difficult context of the COVID-19 pandemic.

Object of research: Tourism and its economic significance

The aim to analyze the concepts of the impact and diversification of tourism as a phenomenon on other sectors during the COVID-19 pandemic.

Results. The composition of the tourism business influences the economic development of all its components, and its safe existence is equally important. It directly depends on the country's economy, state funds, culture of the population, their desire to join the important concept of business organization and development, the focused approach of state and public institutions in solving business stability problems, etc. An important focus encourages the development of new ideas regardless of the impact of COVID-19
\end{abstract}

The used methodology is justified - scientific literature analysis.

Key words: Tourism, economic sector, internationalism, cooperation, international business, COVID-19.

\section{Statement of the problem}

The new COVID-19 virus is challenging the world. This virus has spread greatly across the continent causing many negative factors. 2019 The first cases of coronavirus have been reported in Wuhan, China [1]. With a large global population movement, there are concerns that the virus could spread and reach pandemic levels. That's what happened. Urbanization and glo- balization are driving the rapid spread of the virus [2], but tourism clearly plays an important role in exacerbating emerging public health crises. Coronavirus is currently prevalent across the continent. It spreads in a similar way to the flu. Therefore, protecting people places various constraints on protecting people's lives. People are encouraged to stay at home, events are not organized, the opening hours of restaurants and bars

Tourism - a tool for economic diversification for other sectors 
are limited, safe distances must be maintained everywhere, borders between countries must be closed, all of these factors are causing the most serious disturbances in the world economy

Relevance of the topic. Given the current coronavirus crisis, companies face a variety of business challenges in a complex and rapidly changing environment. Tourism research has focused on the actual and perceived socio-economic contribution of tourism [3]. International tourism has a major impact on society, and in addition to its positive effects, it can hamper the socio-economic well-being of the population living in tourist destinations. In times of crisis and disaster, the negative effects of international tourism may intensify. The rapid movement of the COVID-19 outbreak makes it very difficult to monitor and predict the economic, social and cultural impact. Clearly, the impact on tourism is severe, with countries closing borders and airlines cutting back on their services or even leaving the business.

Probleminis klausimas: how has coronavirus affected the tourism business? What impact do tourism business innovations have on other (non) tourism-related sectors, what impact is felt during the COVID-19 pandemic ?

The aim of the study: to analyze the concepts of the impact and diversification of tourism as a phenomenon on other sectors during the COVID-19 pandemic, identifying the impact on tourism business assessment.

\section{Research tasks:}

1. Define how COVID-19 has affected the tourism business?
2. Find out what are the recommended ways to revive the tourism business?

The used methodology is justified - scientific literature analysis.

The concept of the COVID-19 pandemic and its impact on the tourism business

The importance of economic diversification has re-emerged during the COVID-19 global crisis. An analysis of the consequences of previous crises and the loss of income in the post-crisis years has shown that this is making it very difficult for the various business sectors in the countries themselves. For these reasons, diversification of impacts is crucial for the economic resilience of the countries in the sub-region.

Analyzing the research carried out by the researchers, it considers the key elements that should be part of the country's industrial policy in the tourism and hospitality sectors if effective economic diversification is to be promoted; choosing the optimal recovery strategy; promoting publicprivate partnerships. The use of evidence-based criteria makes it possible to assess success and the need for conditions of validity; the importance of promoting principles such as accountability and transparency.

The COVID-19 outbreak is one of the most influential and tragic pandemics of ourtime. Preserving life is an absolute priority right now. However, we also need to start addressing the recovery of the tourism industry, as there are still restrictions on international and domestic travel. The disease crisis is not a new area of tourism. The tourism industry has faced several scenarios in the past. However, the current

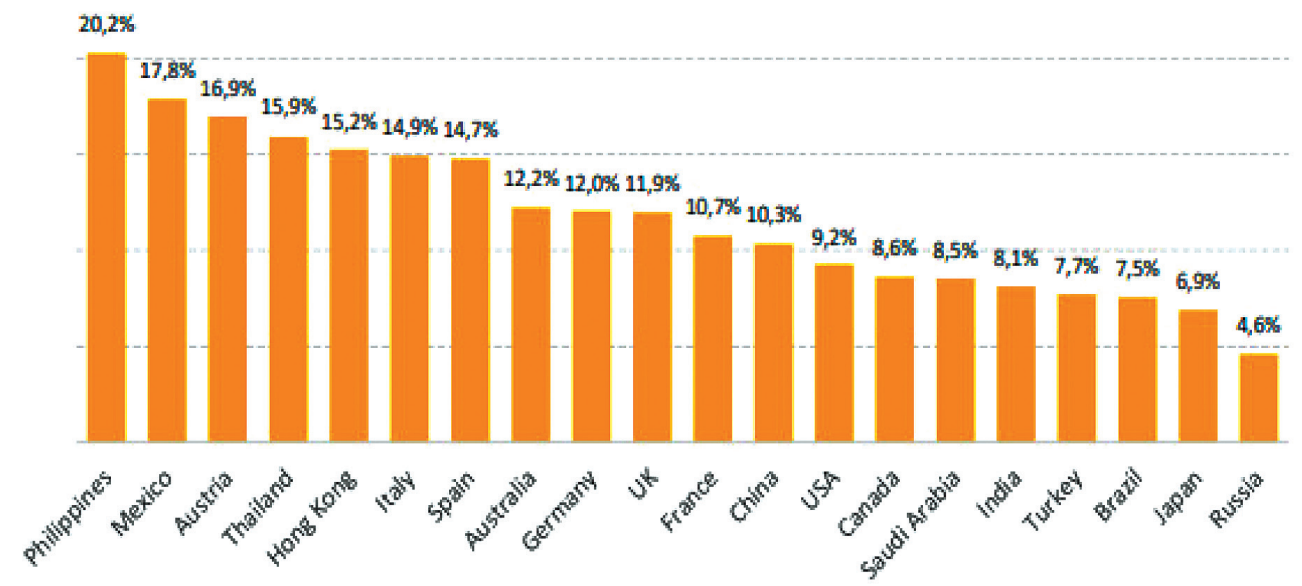

Fig. 1. The contribution of the tourism industry to employment by country, 2018 Source [4] 
crisis has been one of the most damaging. This industry will not look the same after the pandemic, and the tourism industry and the government have a role to play in recovery.

The main market players in all areas of the tourism value chain are: airlines, tour operators, hotels, cruise lines and retailers, which have reduced or stopped production indefinitely, leading to a sudden and complete cessation of their production and revenue streams.

Revenue from tourism is economically important. According to Thams et al. [4] 2018m. Global revenue from tourism was $\$ 1.45$ billion. USD, it was almost three times more than in 2000. (Fig. 1).

From fig. 1 indicates the contribution of people to the tourism industry, the employment of different economies, including both direct and indirect employment. It is important to mention that Italy, a country where COVID-19 has spread significantly, accounts for almost $15 \%$. the workforce works directly or indirectly in the tourism industry. This means that COVID-19 will stop the tourism business and have a significant impact on the country's economy. The current crisis is leading to a sharp decline in employment in the tourism and hospitality industries. This will show the large gaps in total GDP in countries with a very high relative share of tourism in the economy [4].

Falling demand is really reducing the sector and raising prices. According to scientists, the first year after the pandemic is said to be a challenge for the industry, domestic tourism is expected to recover earlier. Increased sanitation costs, combined with capacity reduction rules (well below maximum employment due to social exclusion), can have a significant impact on industrial profitability and further increase prices. An article by Assaf and Scuderi [5] believes that flexible prices and conditions can reduce financial risk in the short term. In addition, pricing strategies can be helpful in changing customers 'perceptions of products. This article also provides a list of strategies on how the tourism industry can contribute to the resolution of the crisis: proper cleaning, disinfection of the premises; possible changes to the premises (hard floors, tables in hotels with security walls, installation of ventilation systems ...), limited contact, personal communication can be gradually switched to technology (this is a more common method of registration and bank transfer payments); restriction of visitors, entertainment / activities outside. Travel confidence and risk perception will affect the pace of industry recovery. In the long run, tourism is likely to return to pre-crisis trends. However, tourists will appreciate hygiene more when choosing accommodation.

Sharma and Nicolau [6] explore four main directions of tourism: hotels, airlines, cruise lines, and car rentals. The survey data show that the assessment of all these areas has decreased. The downturn is significant enough in every industry, so there is a need to worry about the long-term prospects of each industry. It is clear, however, that the most serious concern is with the cruise industry. This is perhaps not surprising. One of the reasons for this is that the ratio of business to leisure travelers in the cruise industry is likely to be lower than in the other industries mentioned. Of course, it is assumed that business travel can recover faster than leisure travel [6]. In addition, concerns in the cruise industry may also be related to the nature of its product: ships, which are essentially enclosed public spaces, this type of people may be afraid of the current crisis. Indeed, the widely reported outbreaks on board the Diamond Princess and other cruise ships confirm people's concerns in the cruise industry. Accordingly, we believe that government assistance to the travel sector should be a priority for the cruise industry.

The role of government is crucial in the recovery of the tourism sector, and when these institutions consider the allocation of funds, the impact of a pandemic on specific sub-sectors that make up the travel sector can provide some advice on how financial assistance can be allocated in this sector [6]. A steady decline in total industry revenue of $30 \%$ or more seems realistic [4], given that operations are currently being shut down for a longer period. The financial challenges for the sector as a whole will continue to increase. Therefore, swift, effective and decisive action is urgently needed, as well as measures from public authorities for the tourism and hospitality industry. These measures shall cover the following areas: 1. Urgent improvement of the liquidity situation of companies in all small and medium-sized tourism companies belonging to the hospitality segment. This must include access to loans and additional credit support. 2. Temporary tax cuts and reductions, in particular transactionbased hotel and airline taxes, which have been hit by the crisis in recent years. 3. Although the aid described in point 1 will significantly increase the debt burden of companies, the prospect of debt reduction needs to be considered. 4. Revitalize markets, along with full empowerment and destination equipment, 
develop a recovery plan for management companies. Market bias subsidies should be avoided [4]. As the economic and operational impact of COVID-19 on the tourism and hospitality industry may not be sufficiently foreseen, research and specific measures will need to be adapted on a regular basis. Industry and geographical features may either change or converge. Acute action will need to be replaced by appropriate time recovery strategies.

The actions of governments to support the local economy have varied from country to country. The tourism industry needs credible government measures to build market confidence and reduce the risk of this virus. In general, the role of governments should change over time during this crisis. From the first phase of liquidity subsidies, they should move quickly to a sustainable recovery and the promotion of innovation. In the article, Assaf and Scuderi [5] make suggestions to the government: to offer interest-free loans, guaranteed loans, creative financing options, and non-repayable grants; provide funding for the promotion of tourist destinations; eliminate or facilitate access to countries recovering from an outbreak in order to increase the flow of international tourism; control of potential predatory investors to protect companies that have become weak as a result of the crisis. These points should help companies recover and allow businesses to prepare for similar factors. COVID-19 tourism research should help to improve our knowledge of informing, promoting, shaping or even leading to possible transformations of such crises. Otherwise, the countries will simply experience one crisis after another COVID-19 has had many social, cultural, economic, and psychological consequences for a variety of tourism stakeholders, some of which will have many years to recover from the effects [7]. The pandemic has therefore created a "fertile" new environment in which tourism researchers can conduct research that benefits consumers. This area can bring a lot of innovation to the tourism business to attract customers, offer new products and engage the public.

It is known that consumers will become more attentive to personal hygiene, so the representatives of the tourism business must take seriously the cleaning of the premises, disinfection, safety during meals, adherence to distances, taking into account all recommendations. Tourism businesses need to work with the government to avoid bankruptcy. Develop a vision for the plan on how to help each other and make the right decisions. A number of solutions have been proposed in this work, so it is important to pay attention to this

Economic diversity and its evaluation

In order to undertake any industrial policy, choices must be made, which means operational priorities and facilitates the process of self-discovery. However, emphasis should be placed on activities that have an additional impact and not just affect the target sectors. To create a new industry, policymakers will have to exercise the right years, even decades ahead.

One of the tangible solutions sought by economic diversity could be the use of qualitative and quantitative measures. An Anoffoff matrix is given as an example.

What is the Ansoff matrix?

The Ansoff matrix, also known as the product / market expansion grid, is a tool that companies use to analyze and plan their growth strategies. The matrix shows four strategies that can be used to grow a company and analyzes the risks associated with each strategy [8] (see Figure 2)

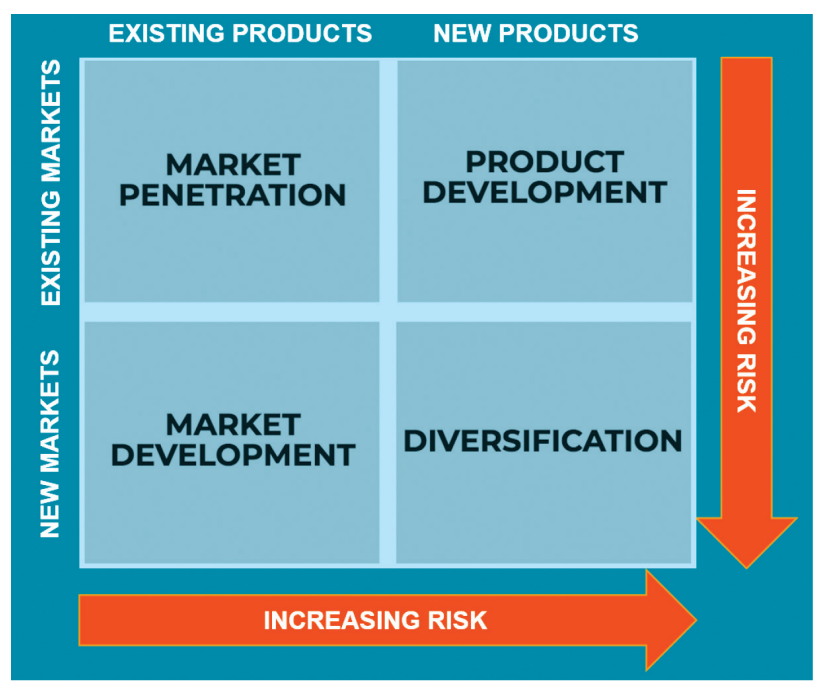

Fig. 2. Four Ansoff Matrix strategies [8]

The four Ansoff Matrix strategies are:

Market penetration: The focus is on increasing the sales of existing products to the existing market.

Product Development: The focus is on introducing new products to the existing market.

Market development: This strategy focuses on entering a new market using existing products.

Diversification: The focus is on entering a new market by introducing new products [9]. Igor Ansoff is one of the pioneers of strategic management planning and in 1957 he developed a matrix a vector of growth. He considered the model of a strategic management consists in conceiving a strategic plan 
to contain the overall strategy of the Organization, detalied into administrative and financial strategies, a strategy based on markets-products, strategied expressed as aims.

The concern regarding the current concerns in the field of the Ansoff matrix study is highlighted by the multitude of studies and specialty articles. This concept continues to be perceived and understood as one of the most important tools for business development and penetration int the business activity field. Numerous studies show that the use of Ansoff's matrix in business development is one of the effective variants that entrepreneurs successfully apply [8].

In order to take any industrial policy, choices have to be made, which means operational priorities and facilitating the process of self-discovery. However, emphasis should be placed on activities that have an additional impact and not just affect the target sectors.

To create a new industry, policymakers will have to exercise the right years, even decades ahead.

It is therefore important to find solutions that identify a tool for economic diversification that sets out long-term development priorities and key success factors for development. Human capital must also be borne in mind when analyzing these priorities. The workforce also increases the efficiency and productivity of the tourism business, as well as intellectual flexibility, which is key to adapting to new technologies and other activities in the sector. Any government in pursuit of diversification must ensure that the system of professional training must also be redesigned so that students are ready to join the current and future industry, which is subject to the hospitality business policy, upon completion of their studies.

\section{Conclusions}

Successful diversification into other sectors requires not only increased market access, but also a review of the investment and policy frameworks that are responsible for structural change. There is a clear need to focus on cross-sectoral cooperation, strengthening related infrastructures, exploring new markets, identifying exports and allocating resources in the tourism sector, diversifying services, reorienting (i.e. new services and new markets). In other words, creating and ensuring added value is essential to creating the desired integration into the world economy.

The coronavirus has negatively affected the tourism business. To help the tourism business recover, it is proposed to improve the tourism industry and comply with the recommendations, as well as government assistance.

In addition, policy intervention should focus on local capacity building. Local content policies can add value domestically by creating new jobs. The country's tourism business policy must promote the development of services, develop human capital competencies, and reduce the backwardness of developed countries. Helping the economy build resilience to withstand unforeseen adverse economic shocks such as COVID-19.

To promote structural changes in economic diversification, to achieve not only stabilization but also a breakthrough of new ideas. Changes in the economy and social life ensure not only rapid the development of a market economy, the consolidation of social democratic processes and certain dysfunctions, including in the field of human security.

After examining the conditions of the competitive environment, no tourism business will be able to engage in commercial activities without providing a perspective in both the short and long term to ensure its economic and financial conditions necessary for profit. The main task is for business leaders, who are always responsible for ensuring that strategic decision-making and decisionmaking can be realized in a strategic model that combines all the interfaces of the companies involved in this sector: economic, financial and accounting, human and technological aspects, etc.

\section{References}

1. Huang, H. L., Allie, R., Gnanasegaran, G., \& Bomanji, J. (2020). COVID19-nuclear medicine departments, be prepared!. Nuclear medicine communications, 41(4), 297.

2. Hilsenrath, J. (2020). Global Viral Outbreaks Like Coronavirus, Once Rare, Will Become More Common. The Wall Street Journal, March, 6.

3. Lindberg, K., \& Johnson, R. L. (1997). The economic values of tourism's social impacts. Annals of tourism research, 24(1), 90-116.

4. Thams, A., Zech, N., Rempel, D., \& Ayia-Koi, A. (2020). An initial assessment of economic impacts and operational challenges for the tourism \& hospitality industry due to COVID-19 (No. 2/2020). IUBH Discussion Papers-Tourismus \& Hospitality.

Tourism $-\mathrm{a}$ tool for economic diversification for other sectors 
5. Assaf, A., \& Scuderi, R. (2020). COVID-19 and the recovery of the tourism industry.

6. Sharma, A., \& Nicolau, J. L. (2020). An open market valuation of the effects of COVID-19 on the travel and tourism industry. Annals of Tourism Research.

7. Sigala, M. (2020). Tourism and COVID-19: impacts and implications for advancing and resetting industry and research. Journal of Business Research.

8. Loredana, E. M. (2017). The use of Ansoff matrix in the field of business. Annals-Economy Series, 2, 141-149.

9. What is the Ansoff Matrix? (2021). Corporate Finance Institute (CFI). https://corporatefinanceinstitute.com/ resources/knowledge/strategy/ansoff-matrix/

ШВАГЖДЕНЕ, БІРУТА - професор, доктор наук кафедри менеджменту спорту і туризму, Литовський Університет Спорту (Каунас, Литва)

E-mail: biruta.svagzdiene@1su.1t

ORCID iD: https://orcid.org/0000-0002-3247-9912

ШТРЕЙМІКЕНЕ, ДАЛЯ - професор, хабіл. доктор наук Інституту наук спорту та інновацій, Литовський Університет Спорту (Каунас, Литва)

E-mail: dalia.streimikiene@1su.lt

ORCID iD: https://orcid.org/0000-0002-3247-9912

ЯСІНСКАС, ЕДМУНДАС - професор, доктор наук, Віце-ректор з науки, Литовський Університет Спорту (Каунас, Литва)

E-mail: edmundas.jasinskas@1su.lt

ORCID iD: https://orcid.org/0000-0003-3158-2974

\title{
ТУРИЗМ ЯК ІНСТРУМЕНТ ЕКОНОМІЧНОЇ ДИВЕРСИФІКАЦІї ДЛЯ ІНШИХ СЕКТОРІВ
}

\begin{abstract}
Анотація
Сприйняття туризму як життєздатної економічної діяльності дуже тісно пов'язане з конкурентоспроможністю. Вважається, що на міжнародному туристичному ринку європейський туризм стикається зі зростаючою конкуренцією з боку країн з економікою, що розвивається на інших континентах. Однак туристичний бізнес розглядається як визначальний фактор конкурентоспроможності економічної диверсифікації. Туризм в Свропейському союзі розглядається як швидкозростаюча область туристичного сектора, яка може сприяти загальному зростанню сектора, одночасно вирішуючи соціальні проблеми і створюючи нові робочі місця. Міжнародний туризм та його економічне значення - маловивчена тема у науковій літературі, та його розвиток через призму економічної диверсифікації чинить все більший вплив на економіку країни. Головна проблема: який вплив інноваціїув туристичному бізнесі надають інші сектори, пов'язані з туризмом, і який вплив відчувається під час пандемії COVID-19. Цілі дослідження: підвищення конкурентоспроможності туризму і, як наслідок, економічний вплив у складних умовах пандемії COVID-19. Об'єкт дослідження: туризм та його економічне значення. Мета - проаналізувати концепції впливу і диверсифікації туризму як явища на інші сектори під час пандемії COVID-19. Отримані результати. Склад туристичного бізнесу впливає на економічний розвиток усіх його складових і його безпечне існування не менш важливо. Це безпосередньо залежить від економіки країни, державних коштів, культури населення, їх прагнення долучитися до важливої концепції організації та розвитку бізнесу, цілеспрямованого підходу державних і громадських інститутів у вирішенні проблем стійкості бізнесу і т. д. Важливий акцент, що туризмустимулює розвиток нових ідей незалежно від впливу COVID -19. Обгрунтовано використану методику - аналіз наукової літератури.
\end{abstract}

Ключові слова: туризм, сектор економіки, інтернаціоналізм, співпраця, міжнародний бізнес, COVID-19.

ШВАГЖДЕНЕ, БИРУТА - профессор, доктор наук кафедры Менеджмента спорта и туризма, Литовский Университет Спорта (Каунас, Литва)

E-mail: biruta.svagzdiene@1su.lt

ORCID iD: https://orcid.org/0000-0001-6016-6019

ШТРЕЙМИКЕНЕ, ДАЛЯ - профессор, хабил. доктор наук Института наук спорта и иноваций, Литовский Университет Спорта (Каунас, Литва)

E-mail: dalia.streimikiene@1su.lt

ORCID iD: https://orcid.org/0000-0002-3247-9912

(C) Svagzdiene, Biruta, Streimikiene, Dalia, Jasinskas, Edmundas, 2021 
ЯСИНСКАС, ЭДМУНДАС-профессор, доктор наук, Вице-ректор по науке, Литовский Университет Спорта (Каунас, Литва)

E-mail: edmundas.jasinskas@1su.1t

ORCID iD: https://orcid.org/0000-0003-3158-2974

\title{
ТУРИЗМ КАК ИНСТРУМЕНТ ЭКОНОМИЧЕСКОЙ ДИВЕРСИФИКАЦИИ ДЛЯ ДРУГИХ СЕКТОРОВ
}

\begin{abstract}
Аннотация
Восприятие туризма как жизнеспособной экономической деятельности очень тесно связано с конкурентоспособностью. Считается, что на международном туристическом рынке европейский туризм сталкивается с растущей конкуренцией со стороны стран с развивающейся экономикой на других континентах. Однако туристический бизнес рассматривается как определяющий фактор конкурентоспособности экономической диверсификации. Туризм в Европейском союзе рассматривается как быстрорастущая область туристического сектора, которая может способствовать общему росту сектора, одновременно решая социальные проблемы и создавая новые рабочие места. Международный туризм и его экономическое значение - малоизученная тема в научной литературе, и его развитие через призму экономической диверсификации оказывает все большее влияние на экономику страны. Главная проблема: какое влияние инновации в туристическом бизнесе оказывают на другие секторы, связанные с туризмом, и какое влияние это ощущается во время пандемии COVID-19? Цели исследования: повышение конкурентоспособности туризма и, как следствие, экономического воздействия в сложных условиях пандемии COVID-19. Объект исследования: туризм и его экономическое значение. Цель - проанализировать концепции воздействия и диверсификации туризма как явления на другие секторы во время пандемии COVID-19. Полученные результаты. Состав туристического бизнеса влияет на экономическое развитие всех его составляющих, и его безопасное существование не менее важно. Это напрямую зависит от экономики страны, государственных средств, культуры населения, их стремления приобщиться к важной концепции организации и развития бизнеса, целенаправленного подхода государственных и общественных институтов в решении проблем устойчивости бизнеса и т. Д. Важный акцент стимулирует развитие новых идей независимо от воздействия COVID-19. Обоснована использованная методика - анализ научной литературы.

Ключевые слова: туризм, сектор экономики, интернационализм, сотрудничество, международный бизнес,
\end{abstract} COVID-19.

(C) The Author(s) 2021

This is an open access article under the Creative Commons CC BY license
Received date 07.02 .2021

Accepted date 18.02.2021

Published date 10.03.2021

How to cite: Svagzdiene Biruta, Streimikiene, Dalia \& Jasinskas, Edmundas. Tourism - a tool for economic diversification for other sectors. Humanities studies: Collection of Scientific Papers. Zaporizhzhia: Zaporizhzhia National University, 2021.7 (84), P. 129-135.

doi: https://doi.org/10.26661/hst-2020-7-84-15

Tourism - a tool for economic diversification for other sectors 